\title{
The Right to be Present at Trial in Criminal Proceedings under Bulgarian Legislation
}

\author{
GEORGE DIMITROV \& RADOSLAVA MAKSHUTOVA
}

\begin{abstract}
Bulgarian Criminal Procedure Code introduces different types of legal means which guarantee the right of the accused person to be present at his/her criminal trial. The introduction and transposition of Directive 2016/343 into the Bulgarian legislation provides more secure guaranties to the accused person in cases when his/her trial is viewed in his/her absence. Bulgarian case-law represents more clarification on the right itself and how it could be efficiently exercised. Judges and prosecutors are becoming more aware of the need to accrue the participation of the accused person in his criminal trial and on this basis, they take additional measures to ensure his/her presence. The statistical data from the Supreme Court of Cassation show that there is an increase in the application of legal remedies that guaranties basic rights and principles of the accused and ensures the conduction of fair trial.
\end{abstract}

Keywords: • Directive 2016/343 • criminal procedure • criminal proceedings $\bullet$ trial in absentia $\bullet$ right to be present $\bullet$ re-trial $\bullet$ Bulgarian Criminal Procedure Code

CoRRESPONDENCE AdDRESS: George Dimitrov, Ph.D., Professor, Law and Internet Foundation, 54 Balgarska Morava Str., Fl. 7, 1303 Sofia, Bulgaria, email: george.dimitrov@ netlaw.bg. Radoslava Makshutova, Dimitrov, Petrov \& Co. Law Firm, 28 Todor Alexandrova Blvd., Fl. 7, 1303 Sofia, Bulgaria, email: radoslava.makshutova@dpc.bg.

https://doi.org/10.4335/978-961-6842-96-9.115-128 (C) 2020 Institute for Local Self-Government Maribor ISBN 978-961-6842-96-9 (pdf) Available online at http://www.lex-localis.press. 


\section{$1 \quad$ Introduction}

In Bulgaria, numerous rights of the accused persons in trial and pretrial proceedings are established at constitutional level. Art. 121.(1) of the Bulgarian Constitution stipulates that the courts shall ensure equality and equal opportunities for all the parties in the judicial trial to present their case, while Art. 31(4) guarantees that the rights of a defendant shall not be restricted beyond what is necessary for the purposes of a fair trial. In the light of these provisions, the Bulgarian Criminal Procedure Code (CPC) establishes strict rules for conducting the proceedings in the absence of the accused (trials in absentia).

\section{$2 \quad$ Legislation overview}

The right to be present at trial was introduced in Bulgarian legislation as early as 1975 . The requirements for conducting the trial in the absence of the accused remain unchanged in the previous CPC (1975) and the new CPC (2005):

O when the person is accused of "serious crime" under the Bulgarian legislation (crime for which the Bulgarian Criminal Code prescribes more than 5 years of imprisonment according to Art. 97, point 7 Criminal Code), his or her presence in the trial is mandatory;

0 when the person is not accused of a serious crime, his or her presence in the proceedings before a court is not mandatory, as far as the absence of the accused does not obstruct the ascertaining of the objective truth;

0 when the absence of the accused does not obstruct the ascertaining of the objective truth (even when he or she is on trial for a serious crime), the court may decide to conduct the proceedings in his or her absence if the following requirements are fulfilled:

- the accused is not found on the address he or she indicated to the authorities or changed the address without informing the authorities;

- the accused's place of residence within the country is not known and could not be determined after a diligent search;

- the accused is not in the country and: a) his or her place of residence in not known, b) he or she cannot be summoned for other reasons, c) he or she was duly served and did not appear before the court without a duly justified reason for his or her absence.

Of particular interest is the notion of "ascertaining the objective truth". This notion is subjective and not defined in law. It relates to the criminal procedure principle that in every case the Court is obliged to find the facts which are objectively true. The judges make an ad hoc assessment whether the ascertaining of the objective truth is possible in the absence of the accused and therefore a trial in absentia could be conducted. In this regard, the provision provides for case-by-case assessment whether a trial in absentia 
would infringe the rights of the accused and the basic principles of Bulgarian criminal procedure.

An additional basis for conducting the trial in the absence of the accused was introduced in 2017 in relation to the new figure of the preliminary trial ${ }^{1}$ - if the absence of the accused does not obstruct the ascertaining of the objective truth, the accused was duly summoned and did not indicate any justified reason for his or her absence and he or she was served all the mandatory documents, the trial can be conducted in his or her absence.

In regard to proceedings before upper level courts, the presence of the accused was not mandatory before courts of second level ${ }^{2}$ until 2015 . Currently, the rules for the presence before second level courts are the same as before the first level courts. Before the Supreme Court of Cassation, the presence of the accused is not mandatory ${ }^{3}$. In re-trial proceedings the presence of the accused is mandatory, and the proceedings must be terminated if the accused does not appear without a justified reason.

\section{$3 \quad$ Summoning of an accused person}

It should be noted that before the adoption of Directive (EU) 2016/343 ("The Directive") the Bulgarian CPC did not contain different provisions regarding the summoning of the accused for the trial compared to the legislation in force. The Bulgarian case-law before 2016 on the matter is in conformity with Article 6 of the European Convention on Human Rights (ECHR) and Resolution (75) 11 on the Criteria Governing Proceedings Held in the Absence of the Accused, adopted by the Committee of Ministers of the Council of Europe.

The means of summoning the accused are the following:

$\bigcirc$ The summons and other documents are handed by the respective official of the court, the pre-trial authorities or the municipality, or, as an exception, by officials of the Ministry of Interior and the Ministry of Justice;

$\bigcirc$ the summoning of military personnel is performed by the respective military authorities;

$\bigcirc$ the summoning of employees could be performed via their employer;

$\bigcirc$ the summoning of accused persons under the age of 18 is performed via their legal representative;

$\bigcirc$ the summoning of arrested, detained or imprisoned persons is performed by the respective authorities;

$O$ the serving and summoning of persons and establishments in other countries is performed in accordance with the international legal assistance treaties;

$\bigcirc$ in urgent matters, the summoning could be performed via telephone, telex, fax or telegram (the latter is absent from the new CPC). 
The following persons can receive summons:

$\bigcirc$ adult member of the family of the accused, and if such is not present -the building manager or the door-keeper, flat mate of neighbour, if they undertake the obligation to deliver it to the accused;

$\bigcirc$ the defence lawyer of the accused.

The summons is always served after the person signs a receipt, and, in cases when he or she declines to sign the receipt, the serving is verified by the signature of at least one other person. A mandatory requisite of the summons is also information regarding the consequences of not participating personally in the proceedings before the court.

The courts and prosecutors have the practice to use all means listed in CPC to summon the accused. All means for summoning, i.e. contacting relatives, friends, checking known addresses, contacting the employer of the accused, nationwide search and others are used often cumulatively.

The summoning via telephone is an often practice when the accused cannot be found on their known addresses and the relatives and friends do not provide their location. The case law requires that courts follow strictly the provisions of the CPC and use such means only when the matter is urgent (Sofia Regional Court. 09.07.2013. Decision 929). These restrictions, however, do not provide enough protection to the right of the accused to be present, as, first, it is hard to prove that the he or she was the person to whom the summoning staff talked on the telephone, and second, that the information was duly and fully delivered without mistakes. In this sense, summoning on the phone may be in breach of Directive 2016/343 and of the obligation of the authorities to inform the accused of the trial. There is no case law of the Supreme Court of Cassation on the matter after the adoption of Directive 2016/343. However, this instrument for summoning the accused may be in breach of the EU legislation.

\section{Requirements for the summoning personnel}

In Bulgaria the personnel who serves the summons is part of the court staff. They must meet the requirements, laid down in the Ordinance for the Judiciary Administration, among which: to be above 18 years old, not convicted, not in relation to a person on an executive position in the court and others. The summoning personnel are appointed after a competition procedure and every chairperson of a court determines additional requirements (for example minimum level of education, good knowledge on procedural laws, good computer skills, good language skills).

\section{Cases in which the accused provided their address to the authorities}

In some cases, the accused may have provided their address to the authorities. Most often, they are obliged to do so because of a supervision measure imposed on them. Under the CPC, when the accused provides their address to the authorities and consequently changes it or was not found on it, the court has enough grounds to conduct a trial in absentia. The 


\section{ENCHANCING THE RIGHT TO BE PRESENT G. Dimitrov \& R. Makshutova: The Right to be Present at Trial in Criminal \\ Proceedings under Bulgarian Legislation}

119

matter is of importance because there was inconsistent case law on the question whether a diligent search must be conducted when the accused provided their address to the authorities and subsequently was not found on it or changed it.

The prevailing case-law (Supreme Court of Cassation, II Criminal Section. 26.06.2000 Decision 348, Supreme Court of Cassation, II Criminal Section. 16.11.2019. Decision 426) and opinions of the doctrine (Chinova, M. p.46). state that in such cases the court must accept that the accused does not have a known place of residence within the country and the authorities must conduct a diligent search. Only after the conduct of a diligent search, which includes nationwide search, the Court can accept that the requirements were fulfilled and that proceedings in the absence of the accused can be conducted. In contradiction to that opinion, in certain decisions (Supreme Court of Cassation, II Criminal Section. 18.04.2001. Decision 182) the Supreme Court of Cassation (SCC) did not require the conduct of a "diligent search" when the accused provided certain address and then was not found on that address - the SCC stated that the accused manifested undue procedural behaviour and therefore the court of lower instance did not have to conduct a diligent search to comply with the requirements of the law. The case law of the Supreme Court of Cassation from 2016 and 2017 (after the adoption of Directive 2016/343) presents the same view. In many cases (Supreme Court of Cassation, I Criminal Section. 07.04.2017. Decision 89, Supreme Court of Cassation, I Criminal Section. 19.10.2016. Decision 197) the Court ruled that if the accused provided an address to the authorities as part of a supervision measure (a.k.a. reporting to the police authorities, house arrest) and then left that address, the Court is not obliged to conduct a diligent search. In such situations the judges assessed that the accused did not display due procedural behaviour and became "uninterested" in the proceedings, therefore choosing not to exercise their right to be present. The SCC based its decision on the case law of the ECHR, which states that when the accused deprived themselves of the opportunity to participate in the proceedings, they cannot be granted a re-trial.

This view is logical considering the provision of Art. 269, where there is a separate basis for conducting the trial in the absence of the accused when they are not found on the address they indicated to the authorities or changed the address without informing the authorities, which does not require further search. Still, the opposite practice is also encountered in the case law (Supreme Court of Cassation, II criminal section. 24.04.2018. Decision 71).

\section{Summoning via electronic means}

Since 2016, citizens can use electronic means when participating in civil or administrative proceedings. This is accomplished via an e-justice portal, which could be used after filing a request to receive summons and other information on concrete proceedings before a specific court. For the moment this system is not used for criminal proceedings, which will be the last step of the e-justice implementation (Dimitrov, G. 2015). 
The biggest challenge before such measures is ensuring secure ways to identify the person and to prove that he or she was the one who was informed/ who received certain information or documents. This problem is serious obstacle before electronic summoning in all proceedings, but even more so in criminal matters, considering the grave consequences of the undue summoning of the accused.

\section{Summoning of accused who are not on the territory of Bulgaria}

The case law on this matter develops together with the international relations, international acts and EU law.

First, in cases where Bulgaria does not have any mutual legal assistance treaty (MLAT) with the country of residence of the accused and there is no information of an exact address in that country, it is permitted for the court to initiate the proceedings in the absence of the accused without procedures for summoning him or her, as such would be legally and objectively impossible. Second, in cases when a MLAT exists, the Court is obliged to use the means provisioned in the MLAT to summon the accused, provided that he or she has a known address in the other country. Otherwise, if the authorities do not use these mechanisms, a re-trial is granted (Sofia Regional Court. 10.12.2015 Decision 1253) or the proceedings begin again from a previous stage. Third, the courts are obliged to use the mechanisms of the European Arrest Warrant wherever the address of the accused is in an EU Member State and he or she has a known address in that Member State. There is almost no case law on the matter before the entry into force of Directive 2016/343. The few decisions dealing with accused in other EU Member States before 2016 stipulate that when he or she has a known address in a Member State, the provisions of the Bulgarian European Arrest Warrant Act must be applied by the competent authorities, otherwise the courts consider that the necessary efforts have not been made(Regional Court - Haskovo. 06.01.2019. Decision 1).

With the development of international and European remedies for collaboration between competent authorities of different countries the means for summoning persons located in other states are used more, including in Bulgaria. The Bulgarian courts, according to acting judges, use all instruments established in mutual legal assistance treaties and the European legislation (the European Arrest Warrant), provided that they know the country of residence of the accused. The authorities question relatives, friends and acquaintances in order to identify the country or countries where the accused may be found. Judges refrain from issuing European Arrest Warrant, when they do not have more concrete information and know only that the accused left the territory of Bulgaria, as in such situations he or she may be in any Member State or third country. Acting judges state that generally the courts use all means to find the accused and start proceedings in their absence only when it is objectively impossible to determine the location of the accused or when the other country refuses to transfer the person. Nevertheless, it is left to the judges to assess which actions are necessary and which actions are unlikely to give result and are therefore unnecessary when searching for the accused. 


\section{ENCHANCING THE Right TO BE PRESENT G. Dimitrov \& R. Makshutova: The Right to be Present at Trial in Criminal \\ Proceedings under Bulgarian Legislation}

The case law on the necessity to issue a European Arrest Warrant states that when the country of residence of the accused is known to the court, such warrant must be issued in order to accept that the court made the due efforts to find the accused (Court of Appeals - Plovdiv. 14.03.2016. Decision 69).

\section{Whether the accused knew of the proceedings}

The question whether the accused knew of the proceedings is quite important in Bulgarian and European case law, legislation and doctrine. First, it is connected to the matter whether the national authorities fulfilled their obligation to inform the accused, or in other words, whether the accused effectively received all necessary information regarding the trial in order to be able to participate in it. Second, the question whether the accused knew of the proceedings is connected with the granting of a re-trial under Bulgarian legislation. The Supreme Court of Cassation (SCC) makes an assessment whether the accused fled or absconded based on evidence that they knew or did not know of the criminal proceedings against them. The constant case law of the SCC stipulates that if it can be proved that the accused knew of the proceedings, then the Court has enough grounds to believe that they fled or absconded. In such cases the SCC assumes that the accused's own behavior was the reason they could not be summoned for the trial/could not participate in the hearings before a court and does not grant a re-trial.

The case-law before 2016 is inconsistent regarding the matter whether the accused knew of the proceedings. In the majority of cases the court decided that, if the first investigation action was conducted with the participation of the accused, he or she knew of the criminal proceedings, even if he or she was not duly summoned for the trial before a court (in Bulgaria, when the accused is summoned for the trial proceedings, he or she is served with a copy of the indictment and is presented with information on the consequences of not appearing before a court). In such cases, the court accepted that the accused became "uninterested" in the proceedings and his or her undue procedural behaviour was the only reason he or she did not know about the beginning of the proceedings before a court. In the majority of cases the Court imposed a supervision measure and the accused was obliged to inform the authorities if he or she changes his/her address ${ }^{4}$.

In Decision 182/18.04.2001 the Court accepted that re-trial could not be granted even if the accused did not try to flee or abscond, because he had an obligation to inform the authorities of his address which he did not fulfil and therefore manifested undue procedural behaviour, which was enough reason to not grant re-trial.

In other cases, the Supreme Court of Cassation decided that even though the first actions of the investigation were conducted with the participation of the accused, he did not know about the beginning of the trial before a court and granted him a re-trial (Supreme Court of Cassation, I Criminal Section. 10.10.2013. Decision 415). The Court ruled that the 
accused clearly knew of the pre-trial proceedings but had to be explicitly informed - of the beginning of the proceedings before a court.

In Decision 415/10.10.2013 the Court took into consideration the fact that the accused was confirmed to have address in another EU Member State, but no efforts were made to contact him there, and also the trial started 4 years after the last investigation actions with the accused's participation.

In Decision 155/17.03.2000, the Court stipulated that, no matter the circumstances, the accused must always be informed of the beginning of a new phase of the criminal proceedings and that the fact that the indictment was not duly served meant that a re-trial must be granted ${ }^{5}$. Such a drastic solution as the latter could be regarded as infringing the balance between the rights of the accused and the society and to not be in compliance with the international acts in the field. Cases in which the accused go into hiding after the first investigation actions are quite common and in many decisions the courts stipulate that it is impossible to serve the indictment on the accused because of the accused's own actions (Supreme Court of Cassation, I Criminal Section. 08.12.2014. Decision 471). The arguments stated here may be the reason the case law after 2016 (the year of adoption of Directive 2016/343) became uniform: if the accused knew of the criminal charge, the courts consider that he or she knew of the proceedings, even if the indictment was not duly served (Court of Cassation, III Criminal Section. 10.04.2018. Decision 45). After the adoption of the Directive there is no case law supporting the view that the accused must be informed of the beginning of every phase, even if his or her own behavior prevented the authorities from serving them with the necessary documents.

If the criminal charge is presented to a lawyer appointed by the state, it is considered that the accused could not have known of the criminal proceedings (Supreme Court of Cassation, I Criminal Section. 03.10.2017. Decision 199).

In cases in which the pre-trial is also conducted in the absence of the accused, the case law is unanimous: it is not possible for the accused to know about the proceedings if he or she did not participate in any of the investigation actions and was not duly notified of the fact that he or she was investigated as part of criminal proceedings (Supreme Court of Cassation, II Criminal Section. 26.06.2000. Decision 348). There is established case law stating that if the criminal charge was presented to a lawyer appointed by the State, the accused could not have known of the proceedings.

\section{$5 \quad$ Diligent search}

According to the Bulgarian legislation, a diligent search must be conducted when the place of residence of the accused in the country is not known. As already mentioned, in the majority of cases the Court stipulated that such diligent search must be conducted 
even if the accused provided his or her address to the competent authorities themselves and then were not found on it.

According to doctrine (Chinova, M. p.46.) and case-law (Supreme Court, I Criminal Section. 19.12.1988. Decision 561), diligent search is the search conducted by the Ministry of the Interior via the Central Bulletin and by indicating concrete data on the means and places for the search. The "Central Bulletin" of the Ministry of the Interior does not exist anymore, the Ministry uses a specialised automated informational system and every regional directorate publishes information about the accused on their website. This search encompasses multiple checks of the properties of the accused, checks whether the accused left the country, checks of all places to which the accused is known to have a relation, of their workplace, as well as of the places for detention and imprisonment. These instruments, which are often enumerated in case law as comprising the "diligent search", are not enlisted in any legislative act. According to case law, the court must wait until the end of the search to initiate the proceedings in the absence of the accused, or otherwise it is considered a procedural infringement (Supreme Court II Criminal Section. 17.03.1993. Decision 147).

The proceedings can be conducted in the absence of the accused only after all necessary actions for finding the accused are objectively conducted and there are explicit data that he or she was not found after the diligent search (Supreme Court of Cassation, III Criminal Section 16.07.2002. Decision 473).

After the adoption of Directive 2016/343, the practices in conducting a diligent search did not change. The biggest problem, according to specialists in criminal law in Bulgaria, is the superficial approach of the competent authorities to the requirements for diligent search. Nevertheless, the courts always make an ad-hoc assessment on the measures taken and their suitability in the concrete case. They rule whether a "diligent search" was actually conducted or not and, consequently, order a re-trial or the re-conducting of the proceedings before the court of lower level, if they find that the measures taken were not effective (Supreme Court of Cassation, II Criminal Section 06.11.2017. Decision 256, Supreme Court of Cassation II Criminal Section 19.07.2017. Decision 143).

Generally, the Bulgarian judges interviewed under the PRESENT project stated that they try to perform all actions for finding the accused, provided in the CPC. In their opinion, proceedings in the absence of the accused must be and are an exception, and it is better for the courts to use all possible means for contacting the accused, even if it is not mandatory by law or by case law. They underline that, first, the accused can provide valuable information on the circumstances of the case and his or her presence could significantly contribute to the ascertaining of the objective truth, and second, that the presence of the accused could help the procedural efficiency and contribute to the shorter duration of the trial. 


\section{Grant of a re-trial}

The re-trial is one of the main instruments used to guarantee the right of the accused to be present. In 2008 it was established that the accused which were duly served with the indictment and documents on their rights, the date of the first hearing and the consequences of non-appearance will not be granted re-trial, if they fled or absconded or if they did not indicate a justified reason for their absence. Unfortunately, the legislative intent for these amendments does not provide clarity on the motives and considerations of the legislator. From the case- law (Supreme Court of Cassation, II Criminal Section. 16.11.2009. Decision 426) it could be concluded that when all due efforts to find the accused were made and he or she was still not present at the trial, the Court ruled that he or she fled or absconded and did not grant a re-trial. Therefore, in such cases the Court still issues a decision on the request and makes an assessment based on all the circumstances of the case, but if it finds that the accused manifested undue procedural behavior, it does not grant the re-trial.

\section{$7 \quad$ Obligation to provide information to the accused}

Directive 2016/343 imposes certain obligations on Member States regarding the information provided to the accused on their rights under the Directive.

\section{The obligation to inform about the consequences of non-appearance}

The obligation to inform duly the suspect or accused of the consequences of nonappearance did not exist in the old CPC (1975). However, it was introduced in the new CPC with an amendment from 2008. The authorities have the obligation to include this information in the documentation served to the accused before the start of the trial, together with the indictment and information on the first hearing from the trial.

\section{The Obligation to inform of the possibility to challenge the decision and of the right to a new trial or to another legal remedy}

It should be noted that this obligation is not explicitly established in the CPC. It is not a practice for Bulgarian courts to include this information in their decisions and the authorities executing the apprehension of the accused do not provide them with the written informational document required by the Directive.

\section{Statistical data on the right to be present}

In the course of the PRESENT Project, a thorough research was conducted and data on trials in absentia and the compliance with the right to be present of the accused from 68 district courts and 19 regional courts, as well as from the Supreme Court of Cassation, was gathered. 


\section{Trials in absentia in the case law of the district courts}

The first noticeable tendency is that there is a significant discrepancy in the number of trials in absentia in smaller district courts, although they have the same average number of criminal proceedings per year. The reasons for this discrepancy identified are two:

0 in some courts there was a rise in trials in absentia because of the migrant movements, especially in 2013 and 2014. In some courts it is noticeable that many of the trials in absentia were conducted against foreign citizens, who were persecuted for unlawful crossing of the border.

0 in some courts the abovementioned tendency is not present, and all categories of crimes are processed in absentia. From the court acts available to the public it could be concluded that certain judges tend to conduct trials in absentia.

The second noticeable tendency is the accused in trials conducted in absentia to be convicted.

The third noticeable tendency is all district courts report close to no trials terminated because of infringements of the right to be present.

\section{Trials in absentia in the case law of the regional courts}

The regional courts act as first or second level court, depending on the degree of seriousness of the crime. They have the right to conduct a trial in absentia and make a separate assessment on the fulfillment of the requirements for conducting trial in absentia.

- Most regional courts from which information was received, report 10 or less trials conducted in absentia in the last 5 years with some of them reporting that they did not have such cases. These statistics may be due to multiple circumstances: first, regional courts rule as first instance on cases involving more serious crimes, for which the presence of the accused is mandatory; second, there is higher probability for the accused to be present when the court is acting as a second instance, especially when he or she appealed and thus initiated the proceedings, but also in other situations. The regional courts conduct a second procedure for finding the accused, whose presence in the appeal proceedings is mandatory in trials for serious crimes since 2015. All of these factors most likely contribute to the low percentage of trials conducted in absentia before regional courts.

0 The tendency for low percentage of acquainted persons when conducting the trial in absentia is also noticeable in the case law of regional courts.

- All regional courts report close to no trials terminated because of infringements of the right to be present.

\section{Re-trial}

In Bulgaria the re-trial is a main instrument used to defend the rights of the persons, against whom a trial in absentia was conducted. The CPC stipulates that a re-trial is granted when the accused did not flee or abscond. The latter is assessed in proceedings before the 
Supreme Court of Cassation (SCC) following the principle audi alteram partem (adversarial process).

The data gathered from the SCC shows that in 2017, after the adoption of Directive $2016 / 343$, the number of requests for a re-trial after the trial was conducted in absentia has significantly decreased.

The data gathered permit the conclusion that:

○ first, in 2017 the courts conducted significantly less trials in absentia which the accused found necessary to appeal using the possibility for a re-trial;

0 second, in the last 3 years significantly more acts of the courts issued in absentia were rendered compliant with the Bulgarian and European legislation in the field, es well as the European standards of fair trial.

Based on the interviews and on the evaluation of case law conducted, it can be concluded that the statistics of the SCC described above are result of the more extensive use of remedies to find the accused in the last 3 years. When all reasonable instruments have been used, it is easier for the court to rule that that the right to be present of the accused was not violated.

\section{Conclusion}

The provisions in Bulgarian legislation on the right to be present have not undergone many changes in the last decades. The reasons are various: first, before the adoption of Directive 2016/343, the Bulgarian legislation provided the guarantees required by the international acts in the field and did not contradict European human rights standards regarding the right to be present, which led to overall compliance with the requirements of the Directive; second, as the research carried out under the PRESENT project indicated, the case law of Bulgarian courts does not show many infringements of the right to be present.

The right to be present is established as one of the main rights of the accused in Bulgarian criminal procedure. The case law is gradually introducing stricter rules for summoning the accused, for example it requires the means of the European Arrest Warrant and Mutual Legal Assistance Treaties to be used in every case possible and a diligent search to be conducted even if the accused provided an address themselves and subsequently cannot be found on it. The national judges realise the importance of the participation of the accused in the proceedings and implement all measures provided in CPC to find the accused; if they do not apply the necessary measures, their decisions are repealed by the higher court or a re-trial is granted. The case law on the matter whether the accused knew of the proceedings was inconsistent, but after 2016 the courts rule that if the accused knows of the criminal charge, then it is considered that he or she knows of the proceedings before a court, even if the indictment was not duly served. The right to re-trial is one of the main tools used to guarantee the right to be present in Bulgarian criminal procedure; 
re-trial is granted after an assessment whether the accused fled or absconded; the Bulgarian case-law bases its decisions on the case law of the European Court of Human Rights which stipulates that if the accused is uninterested in the proceedings, the court is allowed to conduct a trial in absentia.

\section{Notes:}

${ }^{1}$ The preliminary hearing is conducted after the deposition of the indictment in the Court. In this hearing, the Court discusses preliminary questions, inter alia: is the court competent to conduct the proceedings; are there grounds for suspension or termination of the proceedings; are there significant breaches of procedure during the pre-trial phase which seriously infringe the rights of the accused or other parties; are there grounds for applying special procedural rules; requests for gathering new evidence; the scheduling of the first hearing of the trial. Before the conduct of the preliminary hearing, the Court sends to the accused the indictment, together with information of the date of the preliminary hearing, information on the accused's procedural rights and information on the consequences of non-appearance before the Court.

${ }^{2}$ Courts of second level in criminal proceedings in Bulgaria have all the powers of the courts of first level regarding the gathering of evidence and therefore, in the Bulgarian academic field are often referred to as "second first instances".

${ }^{3}$ In Bulgaria the cassation instance cannot determine the facts in criminal proceedings and no new evidence on the facts of the case can be presented or required before it. It rules solely on the application of the law (both material and procedural) in the previous stages and phases of the criminal proceedings.

${ }^{4}$ Some decisions of the Supreme Court of Cassation do not contain explicit information of the imposition of a supervision measure, but instead only stipulate that the accused had an obligation to inform the authorities of any change in his/her address.

${ }^{5}$ In Bulgarian criminal procedure legislation, the criminal proceedings are divided into two parts, called phases - pre-trial phase and trial phase.

\section{References:}

\section{Bulgarian Legal Acts:}

Constitution of the Republic of Bulgaria, adopted on 13 July 1991;

Criminal Code, adopted on 01 May 1968;

Criminal Procedure Code, adopted on 15 November 1974, abolished on 28 October 2005;

Criminal Procedure Code, adopted on 28 October 2005;

Access to Public Information Act, adopted on 07 July 2000;

European Arrest Warrant Act, adopted on 3 June 2005;

Ordinance for the Judiciary Administration issued by the Supreme Judicial Council, adopted on 28 January 2014.

\section{European Union Acts:}

Directive (EU) 2016/343 of the European Parliament and of the Council of 9 March 2016 on the strengthening of certain aspects of the presumption of innocence and of the right to be present at the trial in criminal proceedings; 

under Bulgarian Legislation

\section{Acts of the Council of Europe:}

European Convention for the Protection of Human Rights and Fundamental Freedoms, as amended by Protocols Nos. 11 and 14, supplemented by Protocols Nos. 1, 4, 6, 7, 12, 13 and 16;

\section{Case law in Bulgaria}

Regional Court - Haskovo. 06.01.2019. Decision 1;

Court of Appeals - Plovdiv. 14.03.2016. Decision 69;

Sofia Regional Court. 09.07.2013. Decision 929;

Sofia Regional Court. 10.12.2015. Decision 1253;

Supreme Court, I Criminal Section. 19.12.1988. Decision 561;

Supreme Court II Criminal Section. 17.03.1993. Decision 147;

Supreme Court of Cassation, I Criminal Section. 10.10.2013. Decision 415;

Supreme Court of Cassation, I Criminal Section. 08.12.2014. Decision 471;

Supreme Court of Cassation, I Criminal Section. 19.10.2016. Decision 197;

Supreme Court of Cassation, I Criminal Section. 07.04.2017. Decision 89;

Supreme Court of Cassation, I Criminal Section. 03.10.2017. Decision 199;

Supreme Court of Cassation, II Criminal Section. 26.06.2000 Decision 348;

Supreme Court of Cassation, II Criminal Section. 18.04.2001. Decision 182;

Supreme Court of Cassation II Criminal Section 19.07.2017. Decision 143;

Supreme Court of Cassation, II Criminal Section 06.11.2017. Decision 256;

Supreme Court of Cassation, II Criminal Section. 16.11.2019. Decision 426;

Supreme Court of Cassation, III Criminal Section 16.07.2002. Decision 473;

Supreme Court of Cassation, III Criminal Section. 10.04.2018. Decision 45

\section{Authors publications}

Chinova, M. Summoning of the Accused. National Institute of Justice, available at: www.nij.bg/FileHandler.ashx?folderID=132\&fileID=381

Dimitrov, G. 06.25.2015, E-justice - notion and principles of the reform, Praven Sviat magazine, available at: http://legalworld.bg/45327.elektronno-pravosydie-\%E2\%80\%93-poniatie-iprincipi-na-reformata.html 